Journal of

Business and Strategic

Management

(JBSM)

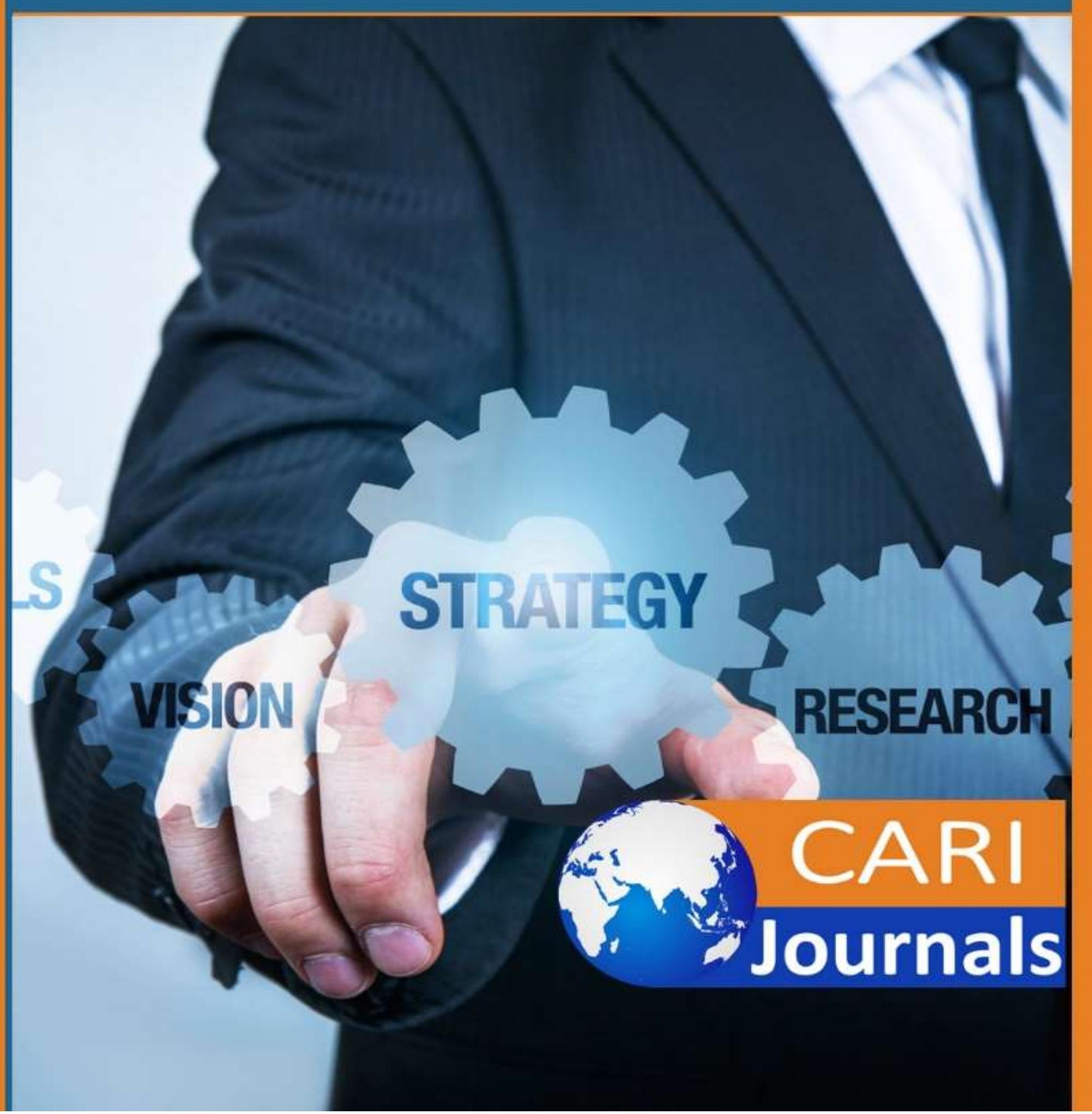


Journal of Business and Strategic Management

ISSN 2520-0402 (Online)

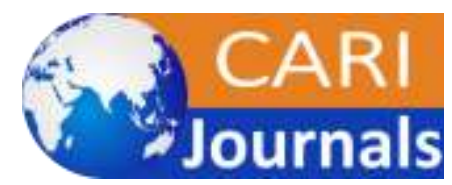

Vol.6, Issue No. 3, pp 1-20, 2021

www.carijournals.org

\title{
EFFECT OF MANAGEMENT STRUCTURE ON QUALITY SERVICE DELIVERY OF MISSION HOSPITALS IN MERU COUNTY, KENYA
}

1*Mary Mugure, MBA Student, School of Business and Economics, Kenya Methodist University

Corresponding Author's email: maryvincent139@gmail.com

${ }^{2}$ Dr Nancy Rintari, PhD, Lecturer, School of Business and Economics, Kenya Methodist University

${ }^{3}$ Dr Stephen Laititi, PhD, Senior Lecturer, School of Business and Economics, Kenya Methodist University

\begin{abstract}
Purpose: The purpose of the study was to examine the relationship between management structure and quality service delivery in mission hospitals in Meru County

Methodology: The study adopted a descriptive research design and primary data was collected from respondents while secondary data was retrieved from published sources. The author used questionnaires as the data collection instrument. The target population was one hundred twentyeight (128) respondents from the mission hospitals in Meru County of Kenya. A pilot study was conducted at Chuka mission hospital in Tharaka Nithi County to establish the reliability of the research instruments. There were eight categories of respondents indicating CEO, Finance Officer, Human Resource Manager, Customer Care Officer, Quality Assurance Officer, Patient, Supplier and Neighbor. The questionnaires were distributed to one person in each category in each hospital making a total of eight questionnaires. The data was analyzed using SPSS version 23 and further explained using descriptive statistics and percentages to enhance understanding and presented in tables and graphs. The study utilized Karl Pearson's coefficient of correlation to describe the association among the variables and establish strength of the relationship between dependent and independent variables.
\end{abstract}

Results: Inferential statistics were used to arrive at the findings where deductions and relationships were established. The findings revealed that there existed a positive relationship between management structure and quality service delivery of mission hospitals in the county as manifested by the inferential results $(r=0.339$; $\mathrm{p}$-value $<0.05)$. After carrying out regression analysis, the research indicated that management structure was insignificant in explaining quality service delivery of mission hospitals.

\section{Unique contribution to theory, policy and practice:}

This study recommends top management implement initiatives aimed at enhancing the effectiveness of management structure to achieve high-quality service delivery in health care provision. The study recommends a project management approach in periodic monitoring and evaluation of the effectiveness of management structure.

Keywords: Management structure, Quality Service, Mission Hospitals, Meru County. 
Journal of Business and Strategic Management

ISSN 2520-0402 (Online)

Vol.6, Issue No. 3, pp 1-20, 2021

$\underline{\text { www.carijournals.org }}$

\subsection{INTRODUCTION}

Globally, the business world has become so dynamic that competition has become very stiff as firms scramble for scarce resources to capture the largest market share. This competition has made businesses think of coming up with strategies that are best for their survival and that enable them to outperform their competitors. Organizations come up with brilliant strategies meant to see their businesses achieve their goals for long-term survival (Guliye, 2016).

One of the strategies that are used by the firm is the optimization of the management structure (Resnick, 2014). The management structure is the management of the organizational hierarchy (Puranam \& Maciejovsky, 2017). The effective management structure should outline task allocation, roles and responsibilities, and chain of command that should be followed by all the employees (Buong \& Ayugi, 2017). The management structure impacts the service quality because it defines the roles and duties and responsibilities; hence creating accountability and preventing conflicts associated with duplication of duties and lack of supervision (Armistead, 2016). Guliye (2016) states that an effective management structure can lead to increased service delivery in organizations. A management structure with the roadmap to pursue strategic direction and help set service delivery goals, deliver customer value, and lead to success (Khayota, 2015).

Several empirical such as Mbulwa and Kinyua (2020) and Islami et al. (2020)studies have confirmed that organizations that have adopted a quality-oriented strategy have achieved improved productivity, improved management of labor relations, improved employee morale, greater customer satisfaction and higher overall performance

According to International Organization for Standardization (ISO), quality service delivery is the characteristics of a service that satisfactorily meets the prescribed requirements of customers. Quality Service delivery can be measured by the number of customer referrals, the low number of complaints from customers, profitability, efficiency and return visits among other indicators (Affisco \& Soliman, 2016).However, according to Hamranová et al. (2020), the measurement of service quality varies from one organization to another. In the context of mission hospitals, the healthcare service concept can be used to assess the service quality of the mission hospitals. For the healthcare institution including hospitals to be regarded as having a high-quality service, it is required to identify the community healthcare problems, establish the solutions to deal with them. The ultimate service goal of the healthcare institutions is to enhance health at the individual, community and population levels (Mosadeghrad, 2014). However, due to the differences in various attributes such as management structure, the concept of service quality can vary from one institution to another (Hamranová et al., 2020).

In Meru County, mission hospitals have implemented various initiatives such as strategic plans, and using benchmarks meant to improve service delivery and achieve their goals but have not been able to fully implement the strategies as intended. However, it is still not clear if the management structure has an impact on the service quality in the context of mission hospitals.

\subsection{Statement of the problem}

Performance of the health sector in Kenya has been wanting across public, some private and even mission hospitals. In the 1970 s to 1990 s, mission hospitals were hailed as the panacea to health needs, especially for poor vulnerable citizens. They had support from mission churches and institutions locally and abroad. However, service delivery has been perceived to decline 
Journal of Business and Strategic Management

ISSN 2520-0402 (Online)

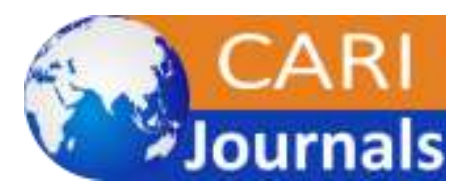

Vol.6, Issue No. 3, pp 1-20, 2021

www.carijournals.org

significantly in mission hospitals in the recent past, the 2000s to date. This is despite most of them having elaborate strategic plans and strong management structure to implement them.

According to research done by Olson, Slater, Hult, and Olson (2018), up to 58\% of organizations perform poorly since they do not correctly implement strategies meant to improve their performance. A study conducted at Kenyatta National Hospital, the largest referral hospital in Kenya on the factors affecting the provision of quality services in the public health sector concluded that low adoption of technology, general low employee capacity, poor communication channels, poor strategy implementation, ineffective management structure and inadequate project funding as the main factors hindering the quality of services delivered in the health facilities to the customers. These factors generally affect the levels of customer satisfaction, customer loyalty and the perception of clients about the services offered in the health facility (Kimani, 2017). The indication that the service quality is affected by the management structure justifies the study on the impact of the structure of the management on the service quality. Furthermore, most of the studies on the effects of service quality on service delivery such as Mosadeghrad (2014) and Abbasi-Moghaddam et al. (2019) have been conducted in the for-profit healthcare segment. Therefore, this study sought to fill this research gap by investigating the extent to which management structure affects the quality-of-service delivery of mission hospitals in Meru County of Kenya.

\subsection{Hypothesis}

This study strived to respond to the following hypothesis:

Ho: There is no relationship between management structure and quality service delivery in Mission Hospitals in Meru County.

\subsection{LITERATURE REVIEW}

2.2 Review of theories

\subsubsection{Resource-Based View Theory}

The resource-based View states that human and organizational resources more than physical, technical or financial ones can provide a firm with a sustained competitive advantage since they can hardly be emulated (Cruz \& Haugan, 2019). The central idea of the resource-based view is how a firm's systems and other attributes can contribute to its overall competitive advantage for the longest period possible. This means that, for a firm to sustain its competitive advantage, the resource has to be valuable, rare, unique and inimitable, which is difficult for other firms to imitate.

Aikins, Ahmed and Adzimah, (2018) states that a sustainable competitive advantage can be created by the human resource systems through the development of competencies that are specific to the firm, giving birth to a unique set of knowledge in the organization and support strong social relationships within an organization.

Additionally, employees are strong assets for sustained competitive advantage and strategic assets to the organization. This uniqueness can be achieved through a well-defined management structure, having the financial capability and the right people for the right job and also 
Journal of Business and Strategic Management

ISSN 2520-0402 (Online)

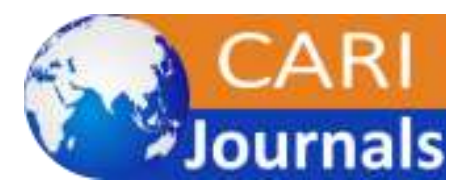

Vol.6, Issue No. 3, pp 1-20, 2021

www.carijournals.org

maintaining good communication channels and timely communication which also provides feedback (Aldehayyat, \& Twaissi, 2015).

The resource-based view also evaluates what a firm possesses, the potential for value generation and finally defines a strategy that allows a firm to capture the maximum of the value in a sustainable way (Mutembei \& Tirimba, 2018). An organization should at all times be able to do things differently or uniquely to ensure they create a niche whereby the people it is serving will always want to come back again and again since no substitutes would supplement what the firm offers.

Concerning this particular study, firms should come up with strategies that are going to make the organization unique and train its employees on how to maintain the standards and be able to use the resources available to produce unique goods and services. When doing things in a unique manner that people love, being sure of the quality and avoiding operating at a loss, ensuring that input can match expectations in output and give returns, ensures success (Powers \& BendallLyon, 2016).

This theory is relevant to this study since the key purpose of every organization is to outperform others, dominate the market and overall, to have sustainable high performance. The theory is relevant to all the research objectives since the management structure needs to be well designed to ensure uniqueness and good flow. The human resource should possess the necessary skills that bond with the organizations' goals and that are unique in the market to enhance the provision of services. Finally, information is a powerful resource which means the way it is conveyed could be a pillar for the organization to enhance the quality of services or if it is poorly done then the organization may fail to communicate its overall critical management decisions, thus would fail to achieve success.

\subsection{Empirical review}

\subsubsection{Management Structure and Quality Service Delivery}

The management structure is a key ingredient in creating an environment that contributes to strategy implementation. Strategy about to be implemented in a big way is influenced by the organizational structure as its impact is felt across the entire organization (Gutman \& Miaoulis, 2017). Gutman and Miaoulis (2017) argued that the implementation affects all the employees in all cadres starting from the top most down to the junior ones in an organization.

Having a very complex management structure would paralyze the process of strategy implementation and service delivery since adjusting the structure will be complex thus strategy implementation may be difficult and, in some instances, may fail completely (Lahap, O'mahony \& Dalrymple (2016). Powers and Bendall-Lyon (2016) state that a management structure should be flexible enough to accommodate any kind of change in an organization. This flexibility helps in handling emergencies and for turnaround strategies in cases of crisis. They continue to argue that if the organizational structure is flexible enough to accommodate adjustments, those affected by the new strategy about to be implemented feel part of the process and resistance is minimum, while services improve.

When an organization has a flexible organizational structure, the decision-making process is not complex thus issues are resolved within the shortest time possible. Musenze and Balunywa 
Journal of Business and Strategic Management

ISSN 2520-0402 (Online)

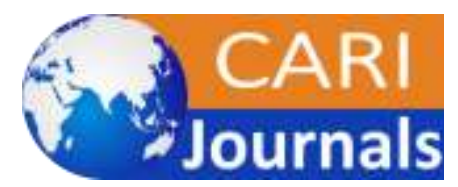

Vol.6, Issue No. 3, pp 1-20, 2021

www.carijournals.org

(2018), did a study on how service delivery was affected by top management support in Nairobi City County Government in Kenya and concluded that the management structure should be well defined with clear guidelines on the responsibilities and roles under each position and should be flexible enough to accommodate most if not all forms of amendments that arise with time.

According to Luxford and Price (2019), the survival useful strategy implementation relies on skilled employees and efficient internal organization systems. For successful strategy implementation, an organization needs to create a center of attention, encourage and maintain gifted managers and workers with appropriate skills and intellectual capital (Anatole, \& Hirschhorn2017). The workers should appreciate how to achieve business objectives, which are very important to attain complete implementation. Assisting the workforce to increase the knowledge, skills and abilities concerned in implementing the strategy requires attention to the employment practice and education (Mwangi, 2016).

Making certain that management and employees are well-equipped to handle present alteration will keep everyone work to attain financial goals. Successful communication is always a key consideration for service delivery. Haghshenas and Davidson (2017) whenever there is a continued communication by top managers, through words and actions, and then there is an assurance to strategy success. According to Brown, Potoski, and Van Slyke (2018), the duty of instigating demanding strategic plan should be allocated to managers with expertise, talents and can be counted on to revolve resolutions and actions into results to convene the recognized objective.

De Araújo (2015) argued that it was important to make certain that the employees who take lead in action have the requisite capabilities. Noeth (2016) effective service delivery depends on the competency of human resources and effective integration of systems. Managers are advised to destroy barriers to effective communication throughout the organization; often involving clients in the communication and information methods. They should also provide precise and appropriate information to those who require it to arrive at conclusions (Usak, Kubiatko, \& Rajabion, 2020). Albejaidi (2016), a good number of employees in organizations lack capabilities even as executives might be possessing leadership abilities for carrying the accomplishment of considered strategies.

Mbulwa and Kinyua (2020) both emphasized the significance of effective governance. Individuals, not businesses, wield the power of good governance practice, according to Mfene (2019), who argued that, like many active members of the board had indicated, it is individuals, not corporations that make decisions. Good governance practices are becoming increasingly critical for effective organizational performance, according to research in a range of sectors (Mutembei \& Tirimba, 2018). The idea of good governance can be described broadly as a governing model that achieves the social and economic outcomes that citizens desire (Mutiso \& Kilika, 2017). Good governance denotes a desirable condition of affairs that is frequently defined in terms of several essential elements such as accountability, transparency, corruption prevention, and citizen participation (Nengwekhulu, 2019). It entails, among other things, enhanced public service delivery and efficient economic and social resource management. More crucially, it concerns the quality of the relationship between the government and the governed in terms of providing monitoring and guidance to an institution's management. Governance in 
Journal of Business and Strategic Management

ISSN 2520-0402 (Online)

www.carijournals.org

Vol.6, Issue No. 3, pp 1-20, 2021

nonprofit organizations is the exercise of power and authority in accordance with the organization's declared values.

Weaver and Deolalikar (2004) in their study in Canadian organizations showed that problemsolving skills by the managerial personnel was very crucial and determined the performance of the organization which was mainly anchored on service delivery. They highlighted that most organizations had failed due to a lack of the managerial capacity to problem-solving skills to the ever-dynamic problems that the organizations faced. Managers preferred to apply their intuition to solve basic issues as they happened, according to her research, and critical difficulties were powerful learning moments for many respondents (Tomkinson, 2017). As owner-managers enhance their ability to solve organizational problems via learning, the ability to learn is essential to the success and future growth of companies. This shows that the problem-solving skills of the managerial personnel in an organization directly influence the work performance and the service delivery ability of an organization (Singh, 2016).

Independent

Variable

Dependent variable

\begin{tabular}{|c|c|}
\hline $\begin{array}{l}\text { Management structures } \\
\text { - Complex } \\
\text { - Flexibility } \\
\text { - Employee involvement } \\
\text { - Decision process }\end{array}$ & $\begin{array}{l}\text { Quality service delivery } \\
\text { - Customer complements } \\
\text { - Customer complaints } \\
\text { - Customer satisfied }\end{array}$ \\
\hline
\end{tabular}

3.0 METHODOLOGY

The study adopted a descriptive design. The target population was one hundred and twenty-eight (128) respondents comprising of CEOs, finance officers, human resource managers, Customer care officers, communication or quality assurance officers, suppliers, patients and neighbors. The study adopted purposive, judgmental and simple random sampling to arrive at the sample. The study collected quantitative data using a self-administered questionnaire by the targeted respondents.

The Cronbach alpha was used for the reliability test of each of the research concepts and the reliability of the questionnaire was confirmed by the result generated from Cronbach alpha test. (Cooper \& Schindler, 2011 cited in Taber, 2018) advises that a Cronbach alpha of at least 0.7 is acceptable. The reliability of the questionnaire was greater than 0.7 and therefore was considered reliable for the study. To enhance the reliability of the instruments test, factor analysis was used. Factor analysis was conducted to ensure that all the items in each instrument were based on the study and those variables found to have a factor loading of 0.4 and above were retained for further analysis. Factor analysis, therefore, aided the researcher with the only items that corresponded to the subject dependent on their factor loadings. 


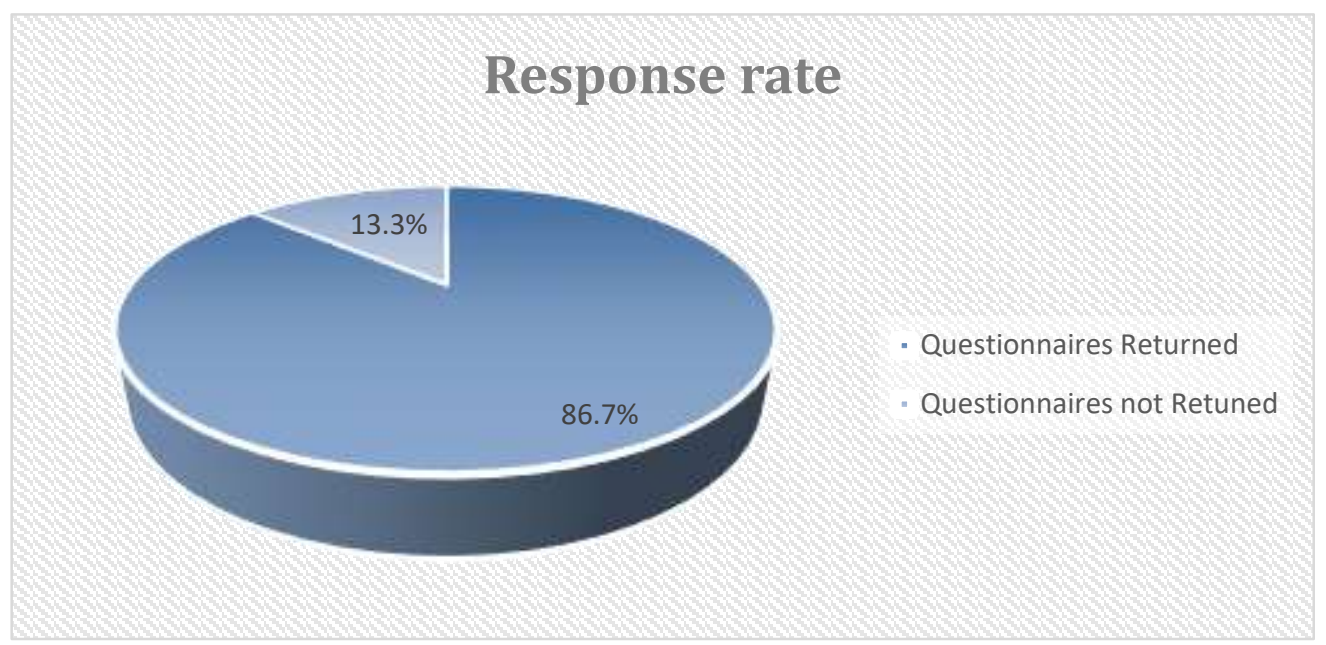

Data was analysed using a statistical package for social science, (SPSS) version 23. Data analysis was carried out using frequencies, percentages regression and correlation. The results were presented in form of tables and graphs. The study used multiple regression analysis to show the effect and influence of the independent variable on the dependent variables.

\subsection{FINDINGS AND PRESENTATION}

\subsection{Response rate}

The study distributed and administered a total of 128 questionnaires to the eight mission hospitals in Meru County. At the end of data collection, 111(86.7\%) out of the 128 questionnaires were returned fully filled as required. A total of 17(13\%) did not return the questionnaires. Therefore, the author considered a response rate of $86.7 \%$ as adequate for analysis. According to Cress well, (2014) a response rate of at least $60 \%$ is sufficient for analysis. The good response rate could be attributed to sustained effort by the researcher to monitor data collection process and clarify the questions asked by respondents where applicable.

\subsection{Reliability of the Data Collection Instrument}

The degree to which data gathering methods and analysis procedures will provide conclusions that are similar to those of previous researchers is referred to as reliability. Data on the impact of strategy implementation of mission hospital on quality service delivery in Meru County, Kenya, was conducted to a reliability test to see how well the technique of data gathering would produce accurate results after multiple trials (Mugenda \& Mugenda, 2003).

The most popular psychometric test for evaluating survey instruments and skills is internal consistency reliability (Zhang, Waszink, \& Wijngaard, 2000). The basic formula for measuring reliability based on internal consistency is Cronbach alpha (Kim \& Cha, 2002). The Cronbach's Alpha internal consistency reliability test was performed on the items that were validated to assess the level to which a survey questionnaire would provide the similar data outcomes after multiple testing. Table 1 shows the internal consistency reliability using the Cronbach alpha test. 
Journal of Business and Strategic Management

ISSN 2520-0402 (Online)

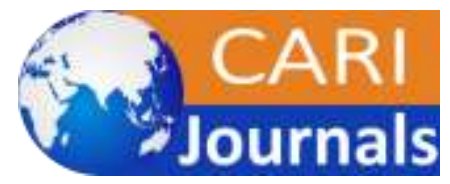

Vol.6, Issue No. 3, pp 1-20, 2021

www.carijournals.org

Table 1: Reliability Analysis

\begin{tabular}{lll}
\hline Study Construct & Cronbach Alpha & No of Items \\
\hline Management structure & 0.811 & 5
\end{tabular}

Source: Pilot Study, 2021

\subsubsection{Background information}

The research sought to establish the demographic characteristics of the study population. The information collected included gender, age in years and highest academic qualification attained.

\subsubsection{Gender and Age Distribution of the Respondents}

The study sought to establish respondents' gender. This was done for the purposes of ensuring the study was not gender biased. As displayed in table 2 the study noted that the majority of the respondents as shown by $65(58.6 \%$ ) were males whereas $46(41.4 \%)$ were females. According to the study findings, this revealed a fair gender balance at Mission Hospitals in Meru County.

Table 2: Gender of the respondents

\begin{tabular}{|c|c|c|c|}
\hline & & Frequency & Percentage \\
\hline Male & & 65 & $58.6 \%$ \\
\hline \multirow[t]{2}{*}{ Female } & & 46 & $41.4 \%$ \\
\hline & 111 & 100 & \\
\hline
\end{tabular}

Figure 3: Age Distribution of the Respondents

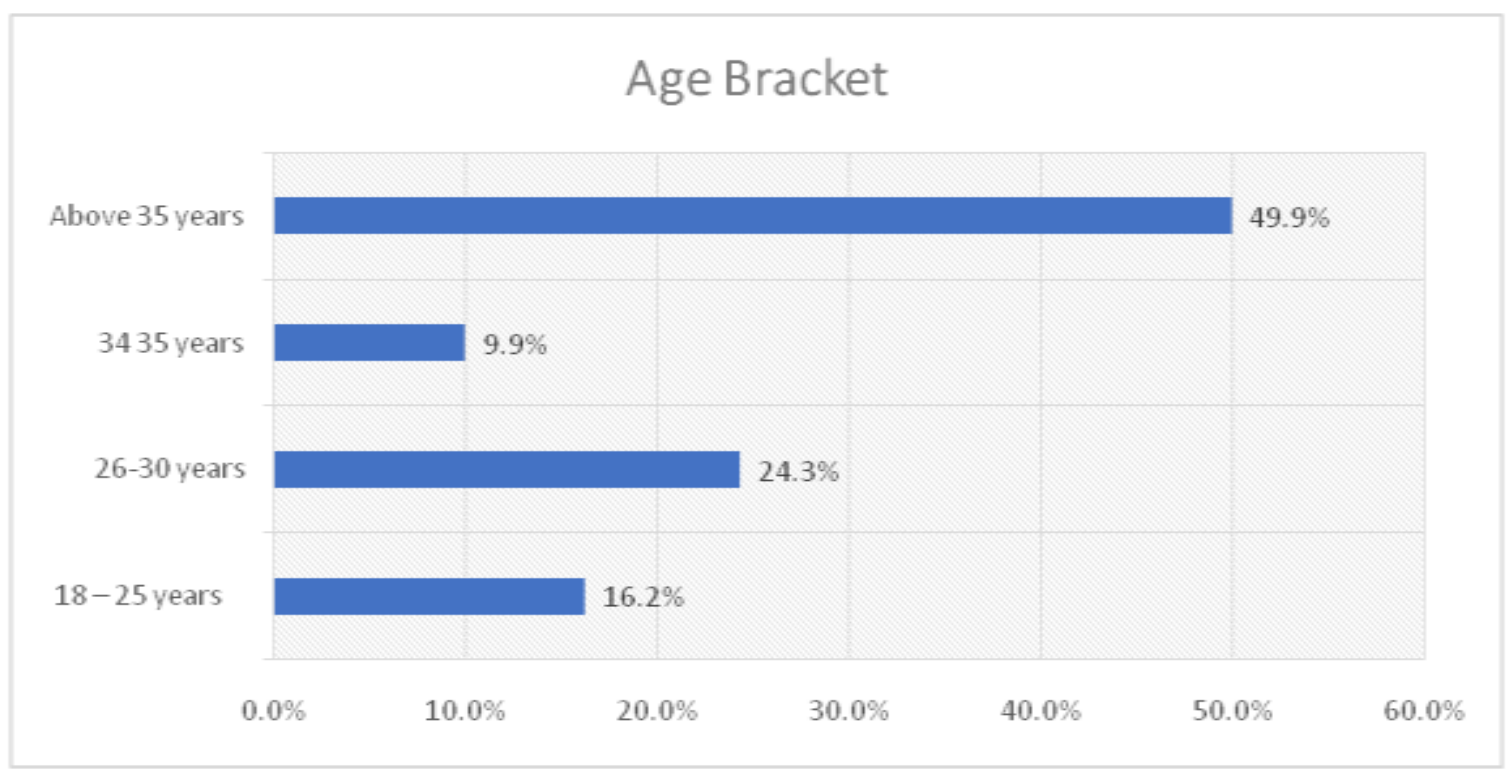


These findings indicated in figure 3 shows that the stakeholders in all the eight Mission Hospitals in Meru County were drawn from all the age categories hence they were mature enough to carry out their duties effectively.

\subsubsection{Level of Education Attained}

The personal uptake/understanding of various issues is determined by one's level of education. Respondents were asked to list their level of educational qualifications in order to determine their capacity to respond to the research questions. The findings are as shown in table 3

Table 3: Level of Education Attained

\begin{tabular}{lll}
\hline Categories & Frequency & Percent \\
\hline Diploma & 14 & 12.6 \\
Undergraduate degree & 51 & 45.9 \\
Master's degree & 28 & 25.2 \\
PhD & 18 & 16.2 \\
Total & $\mathbf{1 1 1}$ & $\mathbf{1 0 0}$ \\
\hline
\end{tabular}

\section{Source: author 2021}

From the research findings in table 3, the study revealed that most of the stakeholders as shown by $51(45.9 \%)$ held an undergraduate degree, $28(25.2 \%)$ of the respondents held masters degree level of academic qualification, $18(16.2 \%)$ of the respondents held doctor of philosophy qualification while 14(12.6\%) of the respondents held diploma level of academic qualification. The respondent's level of education revealed the level of competencies among stakeholders in all the eight Mission Hospitals in Meru County. It also implies that all the respondents had the ability to respond to the research questions without difficulties.

\subsubsection{Length of Service at the Mission Hospitals}

The researcher sought to find out the respondents service experience in terms of years worked at their respective Mission Hospitals in order to determine the level to which they would be relied upon to conclude the research problem. 
Journal of Business and Strategic Management

ISSN 2520-0402 (Online)

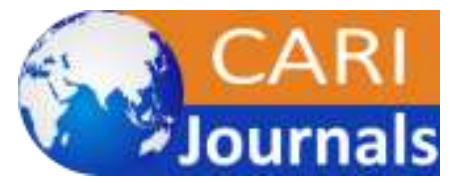

Vol.6, Issue No. 3, pp 1-20, 2021

www.carijournals.org

\section{Table 4: Length of service at the Mission Hospitals}

\begin{tabular}{lll}
\hline Categories & Frequency & Percent \\
\hline $0-2$ years & 23 & 20.7 \\
$3-5$ years & 28 & 25.2 \\
$6-10$ years & 42 & 37.8 \\
11 years and above & 18 & 16.2 \\
Total & $\mathbf{1 1 1}$ & $\mathbf{1 0 0 . 0}$ \\
\hline
\end{tabular}

Source: author 2021

From Table 4, the majority of the stakeholders from all the eight Mission Hospitals in Meru County $42(37.8 \%)$ indicated to have a service experience of 6-10 years, 28(25.2\%) had a service experience of between 3-5 years, 23(20.7\%) had a service experience of between 0-2 years while $18(16.2 \%)$ had a service experience of 11 years and above. The findings revealed that the majority of the respondents had stayed for long at their respective Hospital and hence were able to provide the required information on strategy implementation and quality service delivery

\subsection{Descriptive Analysis}

According to Frankfort-Nachmias and Leon-Guerrero (2009), descriptive research entails using statistical procedures to characterize the population under investigation. The responses to each of the items of the means, as well as the standard deviation of the items, are included in this segment. To assess the respondent's levels of agreement based on the following objective, the analysis used a scale of 1 to 5 where 1 indicated strongly disagree, 2 indicated disagree, 3 indicated neither agree or disagree, 4 implied agree, and 5 implied strongly agree.

\subsection{Management Structure on Quality Service Delivery}

The study sought to determine the effect of management structure on quality service delivery in mission hospitals in Meru County. The results are as shown in Table 5 
Journal of Business and Strategic Management

ISSN 2520-0402 (Online)

Vol.6, Issue No. 3, pp 1-20, 2021

www.carijournals.org

Table 5: Management Structure on Quality Service Delivery

\begin{tabular}{|c|c|c|c|c|c|c|c|}
\hline Opinion & SD & D & $\mathbf{N}$ & $\mathbf{A}$ & $\mathbf{S A}$ & Mean & SD \\
\hline $\begin{array}{l}\text { There is a simple } \\
\text { organizational } \\
\text { structure in the } \\
\text { hospital }\end{array}$ & $8(7.2 \%)$ & $0(0.0 \%)$ & $14(12.6 \%)$ & $27(24.3 \%)$ & $62(55.9 \%)$ & 4.22 & 1.139 \\
\hline $\begin{array}{l}\text { The management } \\
\text { structure in the } \\
\text { hospital is flexible }\end{array}$ & $2(1.8 \%)$ & $5(4.5 \%)$ & $28(25.2 \%)$ & $40(36.0 \%)$ & $36(32.4 \%)$ & 3.93 & 0.960 \\
\hline $\begin{array}{l}\text { The employees are } \\
\text { well involved in the } \\
\text { hospital }\end{array}$ & $22(19.8 \%)$ & $0(0.0 \%)$ & $14(12.6 \%)$ & $17(15.3 \%)$ & $58(52.3 \%)$ & 4.00 & 1.206 \\
\hline $\begin{array}{l}\text { The decision } \\
\text { process is well } \\
\text { defined to solve } \\
\text { most issues }\end{array}$ & $7(3.3 \%)$ & $10(9.0 \%)$ & $11(9.9 \%)$ & $41(36.9 \%)$ & $42(37.7 \%)$ & 3.91 & 1.187 \\
\hline $\begin{array}{l}\text { The departmental } \\
\text { managers provide } \\
\text { enough leadership } \\
\text { and direction. }\end{array}$ & $0(0.0 \%)$ & $7(6.3 \%)$ & $33(29.7 \%)$ & $34(30.6 \%)$ & $37(33.3 \%)$ & 3.90 & 0.943 \\
\hline
\end{tabular}

\section{Source: author 2021}

As per the findings shown in Table 5, there was a general agreement by most of the respondents (79.2\%) that there was a simple organizational structure in their hospital. $12.6 \%$ of the respondents were neutral while only $7.2 \%$ disagreed with the statement. The findings were supported by mean of 4.22 and Standard deviation on 1.139. The study findings as well indicated general agreement by most of the respondents (68.4\%) that the management structure in the hospital was flexible, $25.2 \%$ were neutral to the statement while only6.3\% disagreed with statement. The study outcome was supported by the mean of 3.93 and standard deviation of 0.960. Additionally, most of the respondents (67.6\%) generally agreed that the employees were well involved in the hospital, while $19.8 \%$ disagreed with the opinion and only $12.6 \%$ were neutral. These findings were supported by mean of 4.00 and standard deviation of 1.206. The findings further revealed that most of the respondents $(74.6 \%)$ were in general agreement that the hospitals' decision process was well defined to solve most issues, while $12.3 \%$ disagreed with the opinion and only $9.9 \%$ were neutral. The findings were supported by a mean of 3.91 and standard deviation of 1.187 .

Lastly, there was general agreement by most of the respondents $(63.9 \%)$ that the departmental managers provided enough leadership and direction. However, 29.7\% were neutral while only $6.3 \%$ disagreed with the statement. The findings were supported by a mean of 3.90 and standard deviation of 0.943. The study findings were found to be in line with Burke (2014) who stated that a management structure should be flexible enough to accommodate any kind of change in an organization. This flexibility helps in handling emergencies and for turnaround strategies in 
Journal of Business and Strategic Management

ISSN 2520-0402 (Online)

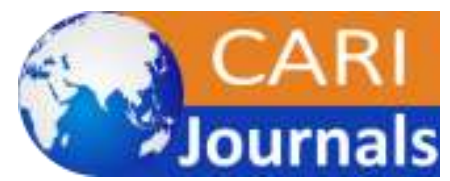

Vol.6, Issue No. 3, pp 1-20, 2021

www.carijournals.org

cases of crisis. He continued to argue that if the organizational structure was flexible enough to accommodate adjustments, those affected by the new changes to be implemented felt part of the process and resistance was minimum.

\subsection{Pearson Correlation Coefficient Matrix}

Correlation analysis was conducted to determine the strength of association between the variables. Karl Pearson's coefficient of correlation was used to measure the level of relationship between the variables at $99 \%$ confidence levels.

Table 6: Pearson Correlation Coefficient Matrix

\begin{tabular}{llll}
\hline & & MS & QSD \\
\hline MS & Pearson Correlation & 1 & \\
QSD & Pearson Correlation & .667 & 1 \\
& Sig. (2-tailed) & .000 &. \\
\hline
\end{tabular}

** Correlation is significant at the 0.01 level (2-tailed), $N=111$

Key: $\boldsymbol{M} \boldsymbol{S}=$ Management structure; $\mathbf{Q S D}=$ Quality of Service Delivery

As shown in Table 6 , the findings revealed a positive and significant relationship between management structure and quality of service delivery $(\mathrm{r}=0.667, p<0.05)$.

\subsection{Regression Analysis}

Regression analysis was used to determine the relationship between study variables.

\subsection{ANOVA}

This section indicates the result of simple linear regression. The model summary indicated in table 7 shows that $64.4 \%$ of the variations in the quality of services delivery in the mission hospitals can be explained by the management structure as indicated by R-square value of 0.644 .

Table 7: Fitness Test for the Overall Model

\begin{tabular}{lllll}
\hline Model & R & R Square & $\begin{array}{l}\text { Adjusted } \\
\text { Square }\end{array}$ & $\begin{array}{l}\text { R Std. Error of the } \\
\text { Estimate }\end{array}$ \\
\hline 1 & .812 & 0.644 & 0.628 & 0.12337 \\
\hline
\end{tabular}

a. Management Structure

Table 8 shows the results of regression ANOVA. The ANOVA analysis presents the influence of the independent variable on quality service delivery in mission hospitals in Meru County. The result of findings showed p-value of 0.000 . This indicated that, the model was statistically significant. This finding therefore concluded that the independent variable had significant effect on quality service delivery of mission hospitals in Meru County. 
Journal of Business and Strategic Management

ISSN 2520-0402 (Online)

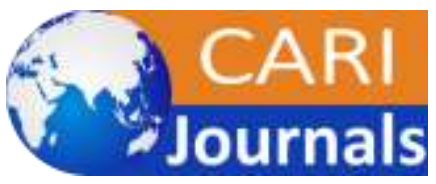

Vol.6, Issue No. 3, pp 1-20, 2021

WwW.carijournals.org

Table 8: Regression ANOVA of management structure and quality of service delivery

\begin{tabular}{lllllll}
\hline \multirow{2}{*}{ Model } & & \multicolumn{2}{c}{ Sum of } & & & \\
Squares & df & Mean Square & F & Sig. \\
\hline 1 & Regression & 18.199 & 1 & 18.199 & 15.918 & $.000(\mathrm{a})$ \\
& Residual & 124.612 & 109 & 1.143 & & \\
& Total & 142.811 & 110 & & & \\
& & &
\end{tabular}

\subsubsection{Coefficient of Determination}

Table 9: presents the coefficient of determination between Management Structure and quality of service delivery. The study found that there was a positive relationship between management structure and quality of service delivery. Management Structure had $r^{2}$ of 0.232 meaning there is a positive relationship.

Table 9: Regression Analysis Results- Coefficient of determination $\left(R^{2}\right)$

\begin{tabular}{|c|c|c|c|c|}
\hline & $\mathbf{R}$ & R Square & Adjusted R Square & $\begin{array}{l}\text { Std. Error of the } \\
\text { Estimate }\end{array}$ \\
\hline Management Structure & $.4818 \mathrm{a}$ & 0.2321 & 0.2127 & 0.17498 \\
\hline
\end{tabular}

\subsection{Regression Analysis Results - Regression Coefficients}

Bivariate regression analysis was used to determine the relationship between Management Structure on quality-of-service delivery of mission hospitals in Meru County would be 1.360. This showed that there was a positive relationship between Management Structure and quality of service delivery of mission hospitals in Meru County.

Table 10: Regression analysis of Management Structure on Quality Service Delivery.

\begin{tabular}{lcccccc}
\hline & $\begin{array}{l}\text { Unstandardized } \\
\text { Coefficients }\end{array}$ & $\begin{array}{l}\text { Standardized } \\
\text { Coefficients }\end{array}$ & t & Sig. \\
& B & Error & Beta & & & Sig. \\
\hline Constant) & 1.360 & 3.93 & & 2.915 & .020 \\
Management Structure & .488 & .221 & .486 & 1.998 & .011 \\
\hline
\end{tabular}

a Dependent Variable: quality of service delivery of mission hospitals in Meru County 
Journal of Business and Strategic Management

ISSN 2520-0402 (Online)

Vol.6, Issue No. 3, pp 1-20, 2021

$\underline{\text { www.carijournals.org }}$

\subsection{Hypotheses Testing Results}

Hypothesis testing was done at 5\% level of significance. Two-tailed test was used because the study's alternative hypothesis was not directional, but composite (Gujarati, 2003). The null hypothesis was accepted because the p-value was more than 0.05

$H_{0:}$ Management Structure has no significant influence on the quality of service delivery of Mission Hospitals in Meru County.

The correlation analysis results in Table 8 show that management structure had significant and positive relationship with the quality-of-service delivery of Mission Hospitals in Meru County at $5 \%$ level of significance. However, although the correlation results shows strong association between management structure and delivery of services, the results of regression analysis shows that management structure does not predict the delivery of services $(p>0.05)$. Therefore, although the association between the variables is significant as indicated in the correlation analysis $(\mathrm{p}<0.05)$, the management structure does not reliability predict the service quality as indicated by regression analysis $(\mathrm{p}>.005)$. This finding led the study to reject the stated null hypothesis at $\mathbf{9 5 \%}$ confidence level. Thus the study concluded that management structure significantly influenced the quality-of-service delivery of the Mission Hospitals in Meru County.

\subsection{SUMMARY, CONCLUSION AND RECOMMENDATIONS}

The study used descriptive statistics to analyze the effects of management structure on qualityof-service delivery of mission hospitals in Meru County. The findings revealed that there was a simple management structure in the hospital and the employees were well involved in service delivery. The regression analysis results indicated that management structure was statistically insignificant $(\mathrm{P}=0.11 ;>0.05)$ in explaining the quality-of-service delivery. The correlation analysis revealed that there existed a positive and significant relationship between management structure and quality-of-service delivery of mission hospitals in Meru County $(\mathrm{r}=.357$; $\mathrm{p}$ value < $0.05)$.

\subsection{Conclusion of the Study}

The study found that Management structure is positively associated with the quality of service delivery of mission hospitals in Meru County. However, the management structure does not reliability predict the quality of service delivery. Therefore, the management of the mission hospitals needs to focus on the ways of improving the effectives of the management structure. Nevertheless, in doing so, they should not ignore other factors that improve the quality of service delivery such as training the staff and communication with the staff.

\section{REFERENCES}

Abbasi-Moghaddam, M. A., Zarei, E., Bagherzadeh, R., Dargahi, H., \& Farrokhi, P. (2019).Evaluation of service quality from patients' viewpoint.BMC Health Services Research, 19(1). https://doi.org/10.1186/s12913-019-3998-0 
Journal of Business and Strategic Management

ISSN 2520-0402 (Online)

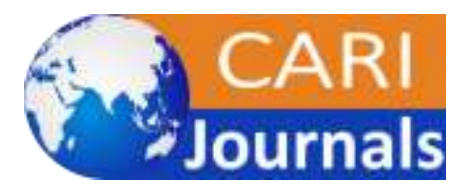

Vol.6, Issue No. 3, pp 1-20, 2021

www.carijournals.org

Adjei, E., \&Mensah, M. (2016). Adopting total quality management to enhance service delivery in medical records: Exploring the case of the Korle-Bu Teaching Hospital in Ghana. Records management journal.

Affisco, J. F., \&Soliman, K. S. (2016). E-government: a strategic operations management framework for service delivery. Business Process Management Journal.

Aikins, I., Ahmed, M., \&Adzimah, E. D. (2018).Assessing the role of quality service delivery in client choice for healthcare: A case study of Bechem Government Hospital and Green Hill Hospital. European Journal of Logistics Purchasing and Supply Chain Management, 2(3), 1-23.

Aldehayyat, J. S., \&Twaissi, N. (2015). Strategic planning and corporate performance relationship in small business firms: Evidence from a Middle East country context. International Journal of Business and Management, 6(8), 255.

Anatole, M., \&Hirschhorn, L. R. (2017).Nurse mentorship to improve the quality of health care delivery in rural Rwanda.Nursing Outlook, 61(3), 137-144.

Armistead, C. (2016). Service operations strategy: framework for matching the service operations task and the service delivery system. International Journal of Service Industry Management, 1(2), 0-0.

Asiamah, N., Mensah, H. K., \&Oteng-Abayie, E. F. (2017). General, target, and accessible population: Demystifying the concepts for effective sampling. The Qualitative Report, 22(6), 1607.

Atkinson, H. (2016). Strategy implementation: a role for the balanced scorecard? Management decision.

Borrero, S., Acosta, A., \& Medina, A. F. (2020). Culture, strategy formulation, and firm performance: a meta-analysis. Academia RevistaLatinoamericana de Administración.

Bradburn, M. J., \& Heller, S. R. (2020). Treatment effects may remain the same even when trial participants differed from the target population. Journal of Clinical Epidemiology, 124, 126-138.

Brown, T. L., Potoski, M., \& Van Slyke, D. M. (2018).Changing modes of service delivery: How past choices structure future choices. Environment and Planning C: Government and Policy, 26(1), 127-143.

Buong, J. A. B., \&Ayugi, M. E. (2017).Uptake of community health strategy on service delivery and utilization in Kenya.

Cheng, Y. (2020). Contingent organization-public relationship (COPR) matters: reconciling the contingency theory of accommodation into the relationship management paradigm. Journal of Public Relations Research, 32(3-4), 140-154.

Corbitt, B. (2018). Managing Quality by Action Research-Improving Quality Service Delivery in Higher Education as a Marketing Strategy. Journal of Marketing for Higher Education, 8(3), 45-62. 
Journal of Business and Strategic Management

ISSN 2520-0402 (Online)

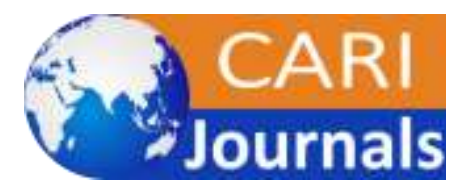

Vol.6, Issue No. 3, pp 1-20, 2021

Www.carijournals.org

Cruz, A. M., \&Haugan, G. L. (2019). Determinants of maintenance performance: A resourcebased view and agency theory approach. Journal of Engineering and Technology Management, 51, 33-47.

De Araújo, J. F. F. E. (2015). Improving public service delivery: the crossroads between NPM and traditional bureaucracy. Public Administration, 79(4), 915-932.

Epetimehin, F. M. (2016). Market segmentation: A tool for improving customer satisfaction and retention in insurance service delivery. Journal of Emerging Trends in Economics and Management Sciences, 2(1), 62-67.

Eriksson, T., Bigi, A., \&Bonera, M. (2020). Think with me, or think for me? On the future role of artificial intelligence in marketing strategy formulation. The TQM Journal.

Gavrilova, T., Kubelskiy, M., Kudryavtsev, D., \&Grinberg, E. (2018).Modeling methods for strategy formulation in a turbulent environment. Strategic Change, 27(4), 369-377.

Govindarajan, V. (2016). A contingency approach to strategy implementation at the businessunit level: integrating administrative mechanisms with strategy. Academy of management Journal, 31(4), 828-853.

Guliye, A. S. (2016). Challenges of strategy implementation in quality service delivery and organizational performance: a case study of Wajir County Government (Doctoral dissertation, University of Nairobi).

Gupta, M. (2015). Strategy formulation for performance improvement of indian corrugated industry: An application of SWOT analysis and QSPM Matrix. Journal of Applied Packaging Research, 7(3), 3.

Gutman, J., \&Miaoulis, G. (2017).Communicating a quality position in service delivery: an application in higher education. Managing Service Quality: An International Journal.

Haghshenas, A., \& Davidson, P. M. (2017). Quality service delivery in cardiac rehabilitation: cross-cultural challenges in an Australian setting. Quality in primary care, 19(4), 215221.

Hambrick, D. C., \&CannellaJr, A. A. (2019). Strategy implementation as substance and selling. Academy of Management Perspectives, 3(4), 278-285.

Hamranová, A., Kokles, M., \&Hrivíková, T. (2020). Approaches to ITSM level measurement and evaluation. SHS Web of Conferences, 83, 01019.

https://doi.org/10.1051/shsconf/20208301019

Hania, B., \& Ahmad, A. A. (2017).Strategy formulation process in large family-based businesses. International Journal of Economics and Management Systems, 2.

Ijeoma, N. B. (2018). Quality Service Delivery as a Competitive Weapon in Corporate Strategy: The Case of Zenith Bank of Nigeria Plc. AFRREV IJAH: An International Journal of Arts and Humanities, 2(3), 90-118.

Islami, X., Mustafa, N., \&TopuzovskaLatkovikj, M. (2020).Linking Porter's generic strategies to firm performance.Future Business Journal, 6(1). https://doi.org/10.1186/s43093-0200009-1 
Journal of Business and Strategic Management

ISSN 2520-0402 (Online)

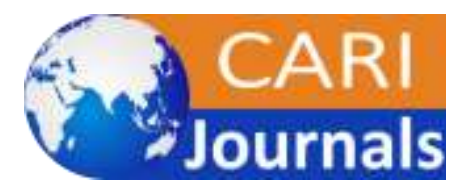

Vol.6, Issue No. 3, pp 1-20, 2021

www.carijournals.org

Khayota, M. C. (2015). Critical Analysis of Strategy Implementation on Organization Performance in Service Delivery: Case of Lake Victoria South Water Services Board in Kisumu. European Journal of Business and Management, 6(30), 192-201.

Kim, S. K. A. (2020). Advanced Mathematical Business Strategy Formulation Design. Mathematics, 8(10), 1642.

Kimani, M. (2017). Effects of Information Communication Technology Strategy Implementation on the Customer Service Delivery in the Insurance Industry in Kenya (Doctoral dissertation, United States International University-Africa).

King'oo, p. M. (2017). Top Management Support and Quality Service Delivery By The Nairobi City County Government, Kenya (Doctoral dissertation, Thesis, Kenyatta University).

Lahap, J., O'mahony, B., \&Dalrymple, J. (2016). The importance of communication in improving service delivery and service quality in the Malaysian hotel industry. Procedia-Social and Behavioral Sciences, 224, 213-220.

Luxford, K. A., \& Price, N. (2019). Service delivery supporting quality cancer care: A national multidisciplinary care project for breast cancer.Journal of Clinical Oncology, 22(14_suppl), 6063-6063.

Mbai, E., Ngui, T., \&Ndiao, O. (2018). Competitive strategies implementation and quality service delivery in Standard Chartered Bank (K) Ltd. International Academic Journal of Human Resource and Business Administration, 3(1), 246-265.

Mbulwa, J., \&Kinyua, G. (2020). The Role Of Strategy Formulation On Service Delivery: A Perspective Of Turkana County In Kenya. International Journal of Innovative Research and Advanced Studies, 8(3), 8.

McAdam, R., Miller, K., \&McSorley, C. (2019).Towards a contingency theory perspective of quality management in enabling strategic alignment. International Journal of Production Economics, 207, 195-209.

Mfene, P. N. (2019). A service delivery perspective on public administration. Journal of Public Administration, 44(si-1), 209-221.

Mohajan, H. K. (2017). Two criteria for good measurements in research: Validity and reliability. Annals of SpiruHaret University. Economic Series, 17(4), 59-82.

Mosadeghrad, A. M. (2014). Factors affecting medical service quality.Iranian Journal of Public Health, 43(2), 210-220. https://www.ncbi.nlm.nih.gov/pmc/articles/PMC4450689/

Mugambi, M. K. (2016). Effects of e-Government strategy on service delivery in the government ministries in kenya (Doctoral dissertation, University of Nairobi).

Musenze, I. A., \&Balunywa, W. (2018). Communication and quality service delivery in Uganda's local government: the mediating influence of total quality management. African Journal of Science, Technology, Innovation and Development, 6(2), 93-103.

Mutembei, G. C., \&Tirimba, O. I. (2018).Role of human resource management strategy in organizational performance in Kenya. International Journal of Scientific and Research Publication, 4(10), 125-141. 
Journal of Business and Strategic Management

ISSN 2520-0402 (Online)

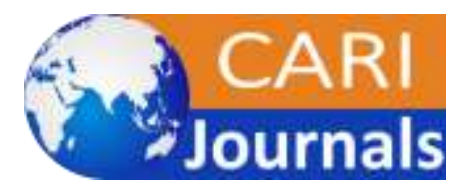

Vol.6, Issue No. 3, pp 1-20, 2021

www.carijournals.org

Mutie, I. M. (2017). Effect of Strategy Implementation on Service Delivery in Government Corporations: A Case of Kenya Bureau of Standards. Journal of Public Policy \& Governance, 1(1), 53-72.

Mutiso, C., \&Kilika, J. M. (2017).Using Human Resource Management Practices to Predict Quality Service Delivery: Case of Public Secondary Schools in Kenya. International Journal of Business and Management, 12(10), 121-131.

Mwangi, P. K. (2016). Influence of Strategy Implementation on the Performance of Manufacturing Small and Medium Firms in Kenya (Doctoral dissertation, JKUAT COHRED).

Nengwekhulu, R. H. (2019). Public service delivery challenges facing the South African public service. Journal of public administration, 44(2), 341-363.

Noeth, A. J. (2016). Knowledge management for service delivery in rural communities. New voices in psychology, 2(1), 31-45.

Nurjono, M., Shrestha, P., \&Vrijhoef, H. J. M. (2019). Implementation fidelity of a strategy to integrate service delivery: learnings from a transitional care program for individuals with complex needs in Singapore. BMC health services research, 19(1), 1-14.

Nzoka, M. S. (2017). Strategic Management Practices Adoption and Service Delivery by the Health Department of Nairobi City County, Kenya (Doctoral dissertation, University of Nairobi).

Olson, E. M., Slater, S. F., Hult, G. T. M., \& Olson, K. M. (2018). The application of human resource management policies within the marketing organization: The impact on business and marketing strategy implementation. Industrial Marketing Management, 69, 62-73. https://eprints.whiterose.ac.uk/142304/

Owuor, S. (2020). Strategy Implementation on Service Delivery in Siaya County Government, Kenya (Doctoral Dissertation, Kenyatta University).

Powers, T. L., \&Bendall-Lyon, D. (2016).Using complaint behavior to improve quality through the structure and process of service delivery. Journal of Consumer Satisfaction, Dissatisfaction and Complaining Behavior, 15, 13.

Puranam, P., \&Maciejovsky, B. (2017).Organizational structure and organizational learning.SSRN Electronic Journal. https://doi.org/10.2139/ssrn.2963250

Resnick, D. (2014). Urban governance and service delivery in African cities: The role of politics and policies. Development Policy Review, 32(s1), s3-s17. https://doi.org/10.1111/dpr.12066

Shimengah, M. M. (2018). Influence of strategic leadership practices on service delivery within county governments in Kenya: A literature review. Journal of Strategic Management, 3(1), 1-13.

Singh, J. (2016). Understanding the structure of consumers' satisfaction evaluations of service delivery. Journal of the academy of marketing science, 19(3), 223-244. 
Journal of Business and Strategic Management

ISSN 2520-0402 (Online)

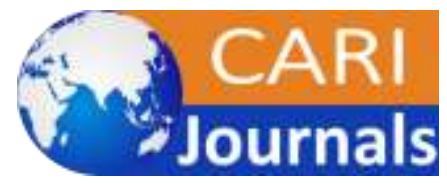

Vol.6, Issue No. 3, pp 1-20, 2021

WwW.carijournals.org

Tomkinson, R. (2017). Shared services in local government: improving service delivery. Routledge.

Usak, M., Kubiatko, M., \&Rajabion, L. (2020). Health care service delivery based on the Internet of things: A systematic and comprehensive study. International Journal of Communication Systems, 33(2), e4179.

Van derWaldt, G. (2016). Establishing a management by projects approach for service delivery. Journal of Public Administration, 36(4), 296-311.

Weaver, M., \&Deolalikar, A. (2004).Economies of scale and scope in Vietnamese hospitals.Social Science \& Medicine, 59(1), 199-208. https://doi.org/10.1016/j.socscimed.2003.10.014

Zhang, Z. H., Waszink, A. C., \&Wijngaard, J. (2000).An instrument for measuring TQM implementation for Chinese manufacturing companies.International Journal of Quality and Reliability Management, 7, 730-755. https://research.rug.nl/en/publications/aninstrument-for-measuring-tqm-implementation-for-chinese-manufa 